Revision Article

\title{
Ethical dilemmas in blood transfusion in Jehovah's Witnesses: A legal-bioethical analysis
}

\author{
Dilemas éticos na hemotransfusão em Testemunhas de Jeová: uma análise jurídico-bioética \\ Dilemas éticos en la transfusión sanguinea de Testigos de Jeová: un análisis jurídico-bioético
}

\begin{abstract}
Objective: To identify knowledge production by healthcare professionals about blood transfusion in Jehovah's Witnesses (JW), listing the therapeutic alternatives for blood transfusion in these individuals and citing the legal, ethical and bioethical standards regarding blood transfusion in JWs. Methods: Data were collected in the LILACS and SciELO databases, Nursing journals and on http://www.google.com.br. Articles focusing on blood transfusion in JWs were included, and texts that were repeated or did not approach this theme were excluded. Content analysis was used. Results: The thematic categories show that the JWs accept self-transfusion and are opposed to the medical practice of blood transfusion, even if it represents the continuity of life. Conclusion: Healthcare professionals experience ethical dilemmas when they need to perform blood transfusion in JWs due to the fact that religious freedom is not an absolute value, and the apparent collision of fundamental rights demands that a decision be made, centered on legal standards and bioethical principles.
\end{abstract}

Descriptors: Blood transfusion; Religion; Bioethics

\section{RESUMO}

Objetivo: Identificar a produção de conhecimento pelos profissionais de saúde acerca da hemotransfusão em Testemunhas de Jeová (TJ), listar as alternativas terapêuticas para a hemotransfusão nesses indivíduos e citar o ordenamento jurídico, ético e bioético no concernente a hemotransfusão em TJ. Métodos: Coletaram-se dados nas bases de dados LILACS e SciELO, periódicos de Enfermagem e no http:// www.google.com.br. Incluiram-se artigos enfocando hemotransfusão em TJ, e excluíram-se os que não abordassem essa temática ou estivessem repetidos. Utilizou-se a análise de conteúdo. Resultados: As categorias temáticas sinalizam que as TJ acatam a auto-transfusão e se contrapõem à prática médica da hemotransfusão, mesmo que ela represente a continuidade da vida. Conclusão: Os profissionais de saúde vivenciam dilemas éticos quando precisam administrar hemotransfusão em TJ devido a liberdade religiosa não ser um valor absoluto e a aparente colisão de direitos fundamentais exigir uma tomada de decisão centrada no ordenamento jurídico e nos princípios bioéticos.

Descritores: Transfusão de sangue; Religião; Bioética

\section{RESUMEN}

Objetivo: Identificar la producción de conocimiento por los profesionales de salud respecto a la transfusión sanguínea de Testigos de Jeova (TJ), listar las alternativas terapéuticas de la transfusión sanguínea en esos individuos y citar la ordenanza jurídica, ética y bioética en lo que concierne a la transfusión sanguínea en TJ. Métodos: Se recolectaron datos en las bases de datos LILACS y SciELO, periódicos de Enfermería y en el http://www.google.com.br. Se incluyeron artículos enfocando la transfusión sanguínea en TJ, y se excluyeron a los que no abordaban esa temática o estaban repetidos. Se utilizó el análisis de contenido. Resultados: Las categorías temáticas señalan que los TJ acatan la auto-transfusión y se contraponen a la práctica médica de la transfusión sanguínea, aunque ella represente la continuidad de la vida. Conclusión: Los profesionales de salud vivencian dilemas éticos cuando precisan realizar transfusiones sanguíneas en TJ debido a que la libertad religiosa no es un valor absoluto y la aparente colisión de derechos fundamentales les exige una toma de decisión centrada en la ordenanza jurídica y en los principios bioéticos.

Descriptores: Transfusión sanguínea; Religión; Bioética

1 Ph.D., Professor of the Nursing Deparment at Universidade Estadual da Paraíba - UEPB - Campina Grande (PB), Brazil.

2 Master in Public Health, Professor of the Nursing Deparment at Universidade Estadual da Paraiba - UEPB - Campina Grande (PB), Brazil.

3 Master in Collective Health, Professor of the Nursing Deparment at Universidade Estadual da Paraíba - UEPB - Campina Grande (PB), Brazil. 


\section{INTRODUCTION}

A healthcare system is prone to ethical questions and dilemmas that, if not solved adequately, can jeopardize professional action, healthcare quality or user autonomy. Bioethical concerns need to be addressed, not only regarding the application of technosciences in the field of emergency situations, but also to ponder the benefits of the technoscientific evolution in the area of persistent situations, like in the case of blood transfusion in Jehovah's Witnesses (JWs).

In Brazil, freedom of speech is granted by article $5^{\text {th }}$, subsection VI of the 1988 Constitution $^{(1)}$, which guarantees the inviolability of conscience and belief, the free exercise of religious worship and the protection of places of worship and their scriptures. This right contributes to the existence of several religious traditions in the country, with the JWs estimated at 637,655 adepts ${ }^{(2)}$.

It is common knowledge that JWs do not accept blood transfusion, even if life is threatened. This refutation is supported in the biblical texts Genesis and Leviticus, which recommend the faithful to abstain from meat for considering that it has a soul, and that the assimilation of blood in the organism by the mouth or the veins would violate God's law. The JWs affirm that the human being's soul lies in the blood and, as such, it cannot be passed on to another person. If that happened, the adept would disobey the commandment of loving God with all his or her soul ${ }^{(2)}$. The prohibition is printed in a personal identification card that contains, on the back, guidelines about healthcare treatment, exemption of the medical team and the adept's signature. Therefore, when the life of a JW is threatened and (s)he refuses blood transfusion, physicians experience a situation that is difficult to solve, since they must choose between respecting the patient's autonomy or the legal devices that govern practice.

When the adept joins this religion, he has to accept, without contestation, all precepts taught and avoid independent thinking. If he makes a transgression, he will be submitted to an audience with a Governing Body, formed by three elders or preachers. This meeting happens behind closed doors, with the only people admitted being the witnesses of the case ${ }^{(3)}$.

The Governing Body can privately admonish the transgressor; suspend his religious privileges; censor him publicly during the weekly meeting; or disfellowship him. In case of disfellowshipping, the other members of the religion have to sever personal relations with the disassociated, even to the point of avoiding simple greetings, and also recommend the minimum possible contact with close relatives (parents, children or spouse). The congregate that disobeys this norm is also subject to disfellowshipping ${ }^{(3)}$.

By considering that the JW doctrine interferes in ethical decision making in the healthcare area regarding blood transfusion; that Brazilian nurses have sought to enhance knowledge in hematology and hemotherapy ${ }^{(4)}$ and that, in our teaching practice, the students manifest doubts about the correct actions in case of blood transfusions that were not consented with by the JWs, this study aimed to identify the production of knowledge by healthcare professionals about blood transfusion in JWs, listing therapeutic alternatives for blood transfusion in these individuals and citing the legal, ethical and bioethical standards concerning this blood transfusion.

\section{METHODS}

This is a literature review, performed from May to June 2007, about "blood transfusion in Jehovah's Witnesses".

Data were collected from the databases of Literatura Latino Americana em Ciências da Saúde (LILACS), Scientific Eletronic Library Online (SciELO) and the Nursing journals: Revista Brasileira de Enfermagem, Revista da Escola de Enfermagem da USP, Revista Latino-Americana de Enfermagem, Acta Paulista Enfermagem, Texto \& Contexto Enfermagem, Revista da Rede Nordeste de Enfermagem-RENE, Revista Brasileira de Hematologia e Hemoterapia and also on the website http://www.google.com.br, with the following keywords: religion, blood transfusion and bioethics. An epistemological cut-off point was established in the year 2002, extending the search up to 2006. This point was established because that was the year when the first articles about this subject were detected. In total, 388 articles were identified, 21 of which were selected. The selection criterion was the focus on blood transfusions in JWs. The articles that did not cover this theme or were repeated in other databases were excluded.

The selected publications were submitted to content analysis: They were read superficially and in-depth; the texts of interest were selected, the selections were standardized and, afterwards, underwent thematic categorization. From this analysis, the following categories emerged: brief history of blood transfusion services in Brazil; production of knowledge about blood transfusion in JW; ethical, bioethical and legal aspects that permeate blood transfusion in JWs. The analysis of the bioethical aspects prioritized principlist bioethics, since this is the best-known paradigm in Brazil, which is also applied in research and clinical practice.

\section{RESULTS}

In the material accessed, only three articles written by nurses focused on blood transfusion in JWs. The 
production of knowledge about this procedure was more frequent in medical journals and, more specifically, within the scope of articles published by surgeons, which aimed to publsh the performance of surgical interventions exempt from the ethical dilemma permeating the physician-patient-procedure relation.

\section{Brief history of blood transfusion services in Brazil}

Until 1900, blood transfusion was an empirical activity. After this date, Karl Landsteiner discovered the blood groups, which contributed to the expansion of procedures involving hemotherapy diagnosis and treatment as a scientific practice ${ }^{(4)}$.

In Brazil, the first organized blood transfusion services appeared in 1920, with the scientific transfusional practice being initiated by surgeons in Rio de Janeiro. In 1950, the I Congresso Paulista de Hemoterapia established the bases for the foundation of the Sociedade Brasileira de Hematologia e Hemoterapia (SBHH). In 1965, the Ministry of Health (MS) created the National Hematology Commission, in charge of creating the blood banks. In the 1980s, the MS established the National Blood Policy ${ }^{(5)}$.

Besides the campaign developed by $\mathrm{SBHH}$ encouraging blood donation and the 1988 Constitution deliberating about the gratuity of blood transfusion, other factors have contributed for Brazilian hemotherapy to adopt its current concepts and care. These factors include: the incidence of AIDS, economic factors, studies about molecular genetics and biotechnology, the concept of Clinical Hemotherapy, emergence of new cellular therapies, renovation and growth of new high-technology equipment, increased offer of hemotherapy and blood bank services and the expressive scientific progress of hemotherapy ${ }^{(5)}$.

\section{Production of knowledge about blood transfusion in JW}

The religious doctrine of Jehovah's Witnesses, founded in the United States by Charles Taze Russell, is contained in the books: "Studies in the Scriptures" and "Translation of the New World of the Scriptures". Its adepts are spread all over the world, predominantly in North America, England, Mexico, Africa, Japan, Bolivia, Brazil and Chile ${ }^{(2)}$. The JWs absolutely refuse to receive total blood transfusion, isolated figurative elements (red blood cells, leucocytes or platelets), or even blood plasma, even if autologous with their own previously-stored blood ${ }^{(6)}$, i.e. this religious adept cannot store their own blood to undergo elective surgery later.

JWs defend the idea that, instead of blood transfusion, recombinant human erythropoietin, recombinant interleukin-11, aminocaproic and tranexamic acids, tissue patch, plasma volume expanders, colloids and hemostatic instruments like electrocautery, lasers or the argon ray coagulator can be used. They mention the existence of 1,000 Commissions for Hospital Relations (CLH) in 230 countries and territories, with over 50,000 medical adepts available to deliver care to these patients, and that there are 100 Centers for Bloodless Medical and Surgical Treatment all over the world ${ }^{(2)}$.

There are three machines in Brazil that perform intraoperatory blood recovery. Access to institutions with this resource happens through contact with the $\mathrm{CLH}^{(7)}$. There is a literature report about the usage of peridural blood stoppers in JW patients, using a closed system that allows for blood collection and its injection in the peridural space, without loss of continuity, after the patient is informed and consents to the treatment ${ }^{(8)}$.

Surgeons published two hemotherapeutic techniques that can be used in the revascularization of the myocardium, valve exchanges, surgical correction of aorta aneurisms, implants of total hip and knee prosthetics and liver transplant. These are recommended for candidates to surgery, regardless of their religious belief ${ }^{(6)}$. One of these techniques is acute normovolemic hemodilution (HNA), which consists in maintaining a minimum level of hemoglobin in the perioperatory period to reduce blood transfusions. In this procedure, blood is diluted in a crystalloid solution, colloid or both, and cannot be separated from the patient, being reinfused during or at the end of the surgery. This procedure is described as follows:

(...) it consists in removing a variable amount of blood, according to the patient's hematocrit, minutes before surgery. This blood is stored with heparin in appropriate bags and connected to the patient's venous system. Hyperbydration follows through another accessway, with saline solutions aiming at hemodiluting the blood. Thus, the blood lost during surgery will have a proportionally lower concentration of red blood cells. At the end of surgery, the previously removed blood is totally and quickly reinfused ${ }^{(7)}$.

The other technique described by the authors is the intra-operatory recovery of blood, which

(...) consists in aspirating the blood from the thoracic, abdominal or pelvic cavity through a heparin-treated conduit, going through a specific machine that performs the following functions: 1 - filtering: separating particles or microaggregates larger than 40 micra from the aspirated content, which are then discarded. It also eliminates fatty microemboli from the aspirated blood, especially during orthopedic surgeries; 2 - centrifugation: process where the supernatant liquid that includes plasma, part of the leucocytes and platelets is discarded; heparin and coagulation factors; 3 - red globe cell washing with saline solution; 4 - storage: in a system connected to the patient's vein and ready for reinfusion, as soon as necessary, which should be done within 4 hours ${ }^{(7)}$. 


\section{Ethical, bioethical and legal aspects of blood transfusion in JWs}

There were situations where the blood transfusion practice was the target of lawsuits by JWs in the material studied. The legal decision in favor of blood transfusion happened as follows:

(...) Therefore, it is uncontestable that both the medical professionals, who should follow their Hippocratic oath to save lives at any cost, and the law professionals, who judges according to what the Law disciplines, must authorize the patient to receive the transfusion, for their own benefit, in order to save their life( ${ }^{(9)}$.

In another lawsuit, the judicial decision published in the media is as follows:

Although there is a constitutional prediction about the right of freedom of religion, it is worth noting that no right is absolute, since it finds limits in other rights equally granted by the Federal Constitution. Therefore, if there is a conflict between two or more fundamental rights or guarantees, the principle of harmonization must be used. In the present case, the aforementioned conflict is evident, since the FC also guarantees the right to life ${ }^{(10)}$.

Blood transfusion in JWs elicits an apparent collision of fundamental rights, such as the right to life, the dignity of the person, religious freedom and its free manifestation, which are guaranteed by the Constitution of the Brazilian Republic. Since these fundamental rights are equally relevant, their practice depends on concrete and legal possibilities $^{(11)}$.

The Brazilian Magna Carta states that life is the greatest good of every man and, in the Penal Code, art. 135, the act of not providing help to a person in grave and imminent danger, when possible, without personal risk to the helper, is considered a crime by omission. The wording of this article is corroborated by art. 146, paragraph $3^{\text {rd }}$, which exempts the physician of responsibility for a medical or surgical intervention without the patient's or their legal representative's consent in case of imminent threat to life ${ }^{(12)}$.

In the specific case of the Nursing professions, Resolution COFEN no. 311/2007(13) recommends the professional to respect, acknowledge and perform actions that will assure the person's right, or that of their legal representative, to decide about their health, treatment, comfort and well-being, turning them exempt from any type of discrimination. It also forbids them to implement or participate in healthcare without the consent of the person or their legal representative, except in cases of imminent risk of death. Therefore, any preventive, diagnostic or therapeutic intervention needs to be based on the bioethical principles of beneficence, maleficence, non-maleficence and autonomy. And it can only be performed with the free consent of the individual involved, based on adequate information.

\section{DISCUSSION}

The need for blood transfusions in JW poses an ethical dilemma to the healthcare team, because this procedure involves the collision of two fundamental rights: the unavailable right to life and the right of refusal due to religious convictions, both equally protected by the Brazilian Constitution. The ethical dilemma is instated in situations of emergency, when the patient is at risk and there is no way of transferring him or her to one of the $\mathrm{CLH}$, or there is no time to try a legal intervention in the face of the JW's or their representative's refusal to accept blood transfusions.

In order to avoid confrontation between the patient and the family members, the surgeons seek to respect the prima facie duty of preserving life, the autonomy and religious freedom by using alternative hemotherapies such as HNA and autologous transfusion, performed in the perioperatory period, using the patient's own blood by using a closed system connected to the JW's veins ${ }^{(6)}$. However, in Brazil, this practice is restricted to three institutions only.

If alternative hemotherapies are impossible, it is up to the physician to decide in favor of blood transfusion to preserve life, supported by legal rights and resolution no. 1021/81 of the Federal Medicine Council and the Code of Medical Ethics, in its articles 56 and 57, despite the JW's refusal ${ }^{(14)}$. When the procedure is elective, with proven need for blood transfusion, it falls under the responsibility of the hospital to request a legal decision to proceed with hemotherapy if it is refused.

Blood transfusion is a clinical treatment whose therapeutic execution, in principle, falls under the responsibility of physicians and laboratory professionals. However, the nurse, as a member of the healthcare team, may have to participate in this procedure, since the Federal Nursing Council approved technical norms for procedures to be performed by Nursing professionals in hemotherapy and bone marrow transplantation.

Blood transfusion in JWs causes an apparent collision of fundamental effects, such as the right of religious freedom and its free manifestation and that of individual autonomy. In this case, these are opposed to the principle of human dignity as the dominant value, and to other legal aspects protected by the Constitution. As such, the situation involves two moral evils: the execution of blood transfusion will cause embarrassment and a moral evil to the JW due to the rules of the doctrine. Non-execution will cause omission, exposing the professional to an ethicallegal judgment. Therefore, the ethical-legal obligation to solve the conflict between these two moral evils is to reject 
both, since choosing evil is not an option ${ }^{(15)}$.

Human dignity is the base of the Brazilian Democratic State and a reference element in case other fundamental rights are mismanaged. As such, both in the legal and in bioethical fields, it has a peculiar meaning, translated as the inadmissible character of every form of instrumentalization of the human being in the fields of biology and medicine ${ }^{(14)}$. Therefore, for ethical decision-making, the apparent collision of fundamental rights of the concrete case will be solved, protecting the right to life and, consequently, the dignity of the person, since these primordial values cannot be exposed to direct and imminent dangers.

The healthcare professionals strive to solve the collision of fundamental rights while also respecting bioethical principles: beneficence - guaranteeing the JW's well-being, maximizing the possible benefits of the necessary interventions; non-maleficence - making an effort not to cause damage to the patient. If there is no imminent risk, they respect the JW's right of autonomy, especially the right of self-determination. These principles are the base of the Term of Consent, a document providing information and clarification about the JW's clinical situation, in a clear and objective way, emphasizing the risks and benefits of the medical intervention to be performed, as well as the possible alternative interventions ${ }^{(1)}$. Whether or not there is a threat to life, this document has to be used in benefit of the JW and the professional.

And, besides the protection of the JW's fundamental rights, the professionals can count on bioethical principles that aid in decision-making, such as: the principle of defense of life as a fundamental reference; the principle of freedom and responsibility, which justifies noncompliance with the JW's refusal, since complying with this attitude would damage the moral conscience of the professional; and the therapeutic principle, which authorizes the professional to intervene in the physical life of the person, provided that the risks and benefits have been previously assessed ${ }^{(15)}$.

As such, when the legal aspects and bioethical principles serve as the base for the solution of a conflict of fundamental rights, the professionals and the JW share the responsibility and the analysis of the best treatment, not only from a physical perspective, but also considering its axiological structure ${ }^{(9)}$.

\section{CONCLUSION}

The JWs are opposed to the medical practice of blood

\section{REFERENCES}

1. Brasil. Constituição, 1988. Constituição da República Federativa do Brasil: Constituição do Brasil, promulgada em 5 de outubro de 1988. Brasília (DF): Senado Federal; 1988. transfusion, even if it represents the continuity of life. Accepting this procedure, besides going against their religious convictions, would expose them to the consequences of the religious code, causing incalculable and irreparable moral, religious and even existential damage.

The ethical dilemmas involving healthcare to JWs can be solved by means of alternative hemotherapies or by transferring such a person to a CLH. If any of these procedures are impossible, there is an apparent collision between the fundamental right to life and the fundamental right to freedom of conscience and belief, which will force the professional to decide in favor of the prevalence of the person's dignity as the limit and base for other rights.

When blood transfusion is imperative and there is no consensual decision between physician and patient, the institution will request judicial authorization to perform the transfusion. Added to the legal aspects, decision making is made legitimized by the bioethical principles within the professional's code of ethics, so that the intervention does not constitute an illegal embarrassment offense. When there is no imminent threat to life and the JW is capable of manifesting his or her will of not having a blood transfusion, his or her autonomy and religious belief must be respected. And, with or without risk to life, the risks and the benefits of hemotherapy need to be clarified, and the Free Consent Term needs to be used, signed by the JWs or their legal representative.

It is concluded that legal regulations do not attribute absolute value to religious freedom and, if a threat to life is imminent, even without the patient's or his or her legal representative's consent, the medical intervention is not considered a crime. That is why, despite the risks for the professionals, there is no history of condemnation in the country.

Furthermore, blood transfusion in JWs requires a discussion involving healthcare practices in harmony with several types of technology, such as the use of instruments and equipment (hard technology), of structured knowledge (hard-light technology) and the establishment of relations between professionals and users (light technology).

This study is limited by the focus on light technologies, because constructs focusing on themes like humanization, welcoming and bonding, among others related to blood transfusions in JWs, could not be found. Hence, further studies are suggested to focus on this theme.

2. Brasil. Sociedade Torre de Vigia de Bíblias e Tratados. Cuidado com a família e tratamento médico para Testemunhas de Jeová. São Paulo: Sociedade Torre de Vigia de Biblias e Tratados; 1995. 
3. Ferreira TR. Questão legal das Testemunhas de Jeová. O Tratamento Arbitrário e o Problema das Testemunhas de Jeová [ Internet]. 2003. [citado 2007 Ago 21]. Disponível em: http://www20.brinkster.com/umadblu/portal/ DiscView.asp?mid=181\&forum_id $=2 \&$

4. Araújo KM, Brandão MAG, Leta J. Um perfil da produção científica de enfermagem em Hematologia, Hemoterapia e Transplante de medula óssea. Acta Paul Enferm. 2007; 20(1): 82-6.

5. Junqueira PC, Rosenblit J, Hamerschlak N. História da Hemoterapia no Brasil. Rev Bras Hematol Hemoter. 2005; 27(3): 201-7.

6. Begliomini H, Begliomini BDS. Técnicas hemoterápicas em cirurgia renal percutânea em paciente testemunha de Jeová. Rev Col Bras Cir. 2005; 32(6): 350-2.

7. Imbelloni LE, Beato L, Ornellas A, Borges CRJ. Manuseio de grave diminuição de hemoglobina em paciente jovem, testemunha de Jeová, submetido à proctocolectomia total: relato de caso. Rev Bras Anestesiol. 2005; 55(5): 538-45.

8. Silva LA, Carli D, Cangiani LM, Gonçalves Filho JBM, Silva IF. Tampão sangüíneo peridural em pacientes testemunhas de Jeová: relato de dois casos. Rev Bras Anestesiol. 2003; 53(5): 633-9.

9. Justiça autoriza transfusão de sangue em testemunha de Jeová. Actus Legitimus [Internet]. 2005 [citado 2008 Abr 20 ]; 1(52):1. Disponível em: http://www.brunocalil. com.br/actus/actus52.htm

10. Brasil. Associação dos Diáconos Batistas do Estado do Rio de Janeiro. Brasil: Transfusão de sangue em Testemunha de Jeová é feita após decisão judicial. 2007. [Internet]. [citado 2008 Jul 10]: 2008. 1 p. Disponível em: http:// www.adiberj.org $/$ modules $/$ news $/$ article.php? storyid $=88$

11. Kaufmann RFM. Colisão de direitos fundamentais: o direito à vida em oposição à liberdade religiosa. O caso dos pacientes testemunhas de Jeová internados em hospitais públicos. Jus Navigandi [nternet]. 2007 [citado 22008 Abr 20]; (1455): 8. Disponível em: http://jus2.uol.com.br/doutrina/ texto.asp?id $=10071$

12. Bitencourt CR. Código penal comentado. São Paulo: Saraiva; 2007.

13. Brasil. Conselho Federal de Enfermagem. Resolução COFEN $n^{\circ} 311$, de 08 de fevereiro de 2007. Aprova a Reformulação do Código de Ética dos Profissionais de Enfermagem [nternet]. 2007. [citado 2008 Jan 14]. Disponível em:http:/ / w w w.portal c of e n. com . b r / $2007 /$ materias.asp?ArticleID $=7221$ \&sectionID $=34$

14. Marini B. O caso das testemunhas de Jeová e a transfusão de sangue: uma análise jurídico-bioética. Jus Navigandi [nternet]. 2005 [citado 2008 Abr 18]; (661): 24. Disponível em: http://jus2.uol.com.br/doutrina/texto.asp?id=6641

15. Sgreccia E. Manual de bioética: I. Fundamentos e ética biomédica.São Paulo: Loyola; 1996. 